Finanse, Rynki Finansowe, Ubezpieczenia nr 3/2017 (87), cz. 1

\title{
Rola audytu wewnętrznego i kontroli zarządczej w szacowaniu ryzyka prowadzonej działalności w jednostkach samorządu terytorialnego
}

\author{
Beata Zaleska*
}

\begin{abstract}
Streszczenie: $\mathrm{Cel}$ - Celem artykułu jest zaprezentowanie wyników badań dotyczących relacji między audytem wewnętrznym a kontrolą zarządczą w szacowaniu ryzyka prowadzonej działalności do ustalenia planu audytu.

Metodologia badania - Zastosowano metody badawcze, takie jak analiza literatury przedmiotu, analiza aktów prawnych i analiza porównawcza. Przeprowadzono ankietę badawczą i wywiad. Ankieta skierowana została do audytorów wewnętrznych, zatrudnionych w jednostkach samorządu terytorialnego i jednostkach budżetowych. Uzupełnieniem badań ankietowych były przeprowadzone z respondentami wywiady. Badania przeprowadzono w 2017 roku.

Wynik - Do sformułowania wniosków posłużyły przeprowadzone badania w jednostkach sfery finansów publicznych a także opublikowane przez NIK wyniki przeprowadzonej w 2011 roku kontroli dotyczącej funkcjonowania kontroli zarządczej w jednostkach samorządu terytorialnego, ze szczególnym uwzględnieniem audytu wewnętrznego.

Oryginalność/wartość - W artykule zaakcentowano problem powiązań między audytem wewnętrznym a kontrolą zarządczą w szacowaniu ryzyka prowadzonej działalności na potrzeby planu audytu wewnętrznego. Autor opracowania nie spotkał się do tej pory z badaniami, które dotyczyły poruszanego problemu.
\end{abstract}

Słowa kluczowe: audyt wewnętrzny, kontrola zarządcza, ryzyko, plan audytu, cele, zadania, mierniki

\section{Wprowadzenie}

Od roku 2010 obowiązuje w sektorze publicznym kontrola zarządcza, która zgodnie z ustawą o finansach publicznych jest ogółem działań, podejmowanych w celu zapewnienia realizacji celów i zadań w sposób zgodny z prawem, efektywny, oszczędny i terminowy. Za kontrolę zarządczą odpowiada kierownik jednostki, który ma zrealizować jej podstawowy cel, jakim jest zarządzanie ryzykiem prowadzonej działalności.

Wspieranie kierownika jednostki w realizacji celów i zadań mieści się w zakresie działań audytu wewnętrznego, który dokonuje systematycznej oceny kontroli zarządczej i wykonuje czynności doradcze (Ustawa, 2009, art. 272). Audyt wewnętrzny jest działalnością niezależną i obiektywną. Ocena kontroli zarządczej przez audyt polega na ustaleniu czy jest ona adekwatna, skuteczna i efektywna. Kontrola przeprowadzana jest na podstawie

\footnotetext{
* dr Beata Zaleska, Politechnika Koszalińska, Wydział Nauk Ekonomicznych, Zakład Rachunkowości, e-mail: b.zaleska@tlen.pl.
} 
rocznego planu, który musi być opracowany do końca roku, na podstawie dokonanej przez audytora analizy ryzyka prowadzonej przez jednostkę działalności. Plan audytu ustalany jest w porozumieniu z kierownikiem jednostki, któremu audyt wewnętrzny bezpośrednio podlega.

Zgodnie z Rozporządzeniem Ministra Finansów w sprawie audytu wewnętrznego oraz informacji o pracy i wynikach tego audytu, przeprowadzający analizę ryzyka audytor wewnętrzny musi między innymi wziąć pod uwagę cele i zadania jednostki oraz ryzyko wpływające na realizację celów i zadań (Rozporządzenie, 2015).

Zgodnie ze standardami kontroli zarządczej to właśnie w jej ramach wyznacza się cele i zadania poszczególnych obszarów działania jednostki, identyfikuje i przypisuje ryzyko do wyszczególnionych celów i zadań, następnie się je analizuje i wskazuje sposób reakcji na nie (Komunikat, 2009). Działania te są związane z zarządzaniem ryzykiem, które ma zwiększyć prawdopodobieństwo osiągnięcia celów i realizację zadań poszczególnych obszarów działalności jednostki.

Na podstawie obowiązujących regulacji prawnych dotyczących kontroli zarządczej i audytu wewnętrznego można postawić tezę, że audytor wewnętrzny na potrzeby stworzenia planu audytu na przyszły rok powinien posiłkować się wyznaczonymi przez kontrolę zarządczą rodzajami ryzyka przyporządkowanymi do celów i zadań, które ma zrealizować jednostka.

Celem artykułu jest zbadanie, czy audytorzy wewnętrzni w jednostkach, w których przeprowadzono badania ankietowe i wywiady, wykorzystują analizę ryzyka przeprowadzoną w ramach kontroli zarządczej do opracowania planu audytu na przyszły rok. Pośrednim celem przeprowadzonych badań jest też określenie relacji między audytem wewnętrznym a kontrolą zarządczą $\mathrm{w}$ zakresie analizy ryzyka.

\section{Metody pomiaru ryzyka w kontroli zarządczej i audycie wewnętrznym}

Zarządzanie ryzykiem jest podstawowym działaniem kontroli zarządczej. Zgodnie ze standardem nr 6 do obowiązków osób odpowiedzialnych za kontrolę zarządczą należy określenie celów i zadań jednostki w rocznej perspektywie oraz monitorowanie ich wykonania za pomocą mierników (Komunikat, 2009). Celom i zadaniom przypisane powinno być podlegające analizie ryzyko związane z możliwością wystąpienia nieprawidłowości przy realizacji działalności jednostki. Analiza ryzyka w kontroli zarządczej polega na jego identyfikacji, ocenie, uszeregowaniu według rodzajów i określeniu sposób postępowania z nim (Ministerstwo Finansów, 2011).

Identyfikacja ryzyka jest procesem powtarzalnym i związanym z planowaniem działalności. W proces powinni być zaangażowani pracownicy, którzy znają specyfikę jednostki, cele i zadania, które ma do zrealizowania, a także uwarunkowania zewnętrzne wpływające na jej funkcjonowanie. Zidentyfikowane ryzyko powinno być przypisane do celów i zadań realizowanych przez odpowiednie komórki organizacyjne, które będą na nie odpowiednio 
reagować. Kierownicy poszczególnych komórek organizacyjnych lub wyznaczeni do tego pracownicy to właściciele ryzyka. Właściciel ryzyka odpowiada za zarządzanie ryzykiem i jego monitorowanie.

Zidentyfikowane ryzyko podlega ocenie, czyli ustaleniu jego istotności. Istotność to wypadkowa prawdopodobieństwa wystąpienia ryzyka i skutków, które może ono spowodować. Ocena ryzyka może być dokonywana różnymi metodami, w zależności od specyfiki jednostki i umiejętności osób, które takiej oceny dokonują. Określenie istotności poszczególnych zidentyfikowanych rodzajów ryzyka pozwala je uszeregować i sporządzić $w$ formie graficznej mapę ryzyka. Na jej podstawie ryzyko przypisane jest do odpowiedniej kategorii. Wyróżnia się ryzyko, wobec którego muszą być podjęte dodatkowe działania, ryzyko, które musi być monitorowane i takie, które nie niesie istotnego zagrożenia dla realizacji celów i zadań.

Sposób reakcji na ryzyko zależy od stopnia jego akceptowalności a także porównania kosztów koniecznych do jego zminimalizowania lub uniknięcia, z korzyściami jakie te działania przyniosą. Informacje o ryzyku powinny być przedstawione w rejestrze ryzyka. Jego minimalna zawartość to podanie zidentyfikowanych rodzajów ryzyka, jego właścicieli, oceny ryzyka, akceptowanego poziomu i sposobu reakcji na ryzyko.

Ocena zarządzania ryzykiem jest podstawowym zadaniem audytora wewnętrznego. Zgodnie z międzynarodowymi standardami audytu wewnętrznego przyjętymi do stosowania w Polsce, ocena ta polega na ustaleniu skuteczności zarządzania ryzykiem i przyczynieniu się do usprawnienia tego zarządzania (Komunikat, 2013). W procesie oceny audytor wewnętrzny bada czy cele jednostki są zgodne z jej misją i ją wspierają, czy zostały wyznaczone i ocenione istotne rodzaje ryzyka, czy został wyznaczony sposób reakcji na ryzyko w odniesieniu do stopnia jego akceptowalności. Przy ocenie zwraca się też uwagę na to czy są rejestrowane informacje o ryzyku w rejestrze ryzyka i na czas przekazywane pracownikom jednostki.

W audycie wewnętrznym rola analizy ryzyka sprowadza się do sporządzenia planu audytu i zidentyfikowaniu obszaru ryzyka, który będzie podlegał badaniu przez audytora. Na podstawie dokonanej analizy ryzyka audytor wybiera zadania, które w danym roku będzie realizował. W analizie ryzyka na potrzeby audytu wewnętrznego bierze się pod uwagę cele i zadania jednostki i ryzyko, które jest do nich przyporządkowane. W analizie ryzyka może brać udział audytor, kierownik jednostki i kierownicy poszczególnych działów. Metody analizy ryzyka przedstawiono w podręczniku audytu wewnętrznego $\mathrm{w}$ administracji publicznej, który został opublikowany przez Ministerstwo Finansów w marcu 2003 roku (Podręcznik, 2003). Zgodnie z nim do analizy ryzyka można zastosować metodę mapy ryzyka, matematyczną, szacunkową i mieszaną. Najprostsza jest metoda szacunkowa, polega na stworzeniu listy rankingowej na podstawie poziomu ryzyka przypisanego do konkretnych zadań audytowych. Metoda wymaga od audytora dobrej znajomości jednostki i jest polecana dla wieloosobowych komórek audytu wewnętrznego ze względu na uwiarygodnienie wyników. 
Metoda matematyczna stosowana przy wykorzystaniu arkusza kalkulacyjnego - jest uważana za najlepiej udokumentowaną metodę analizy ryzyka. Ryzyko obszarów działalności jednostki wyznacza audytor na podstawie swojego osądu, biorąc pod uwagę priorytety kierownika jednostki i datę ostatniej kontroli, dokonanej w obszarze działalności, dla którego wyznaczane jest ryzyko.

Metoda mieszana wykorzystywana jest najczęściej do oceny czynników ryzyka przypisanych do procesów, które są realizowane w obszarach działalności jednostki wybranych do kontroli przez audytora wewnętrznego w rocznym planie audytu. Dla obszaru działalności jednostki, dla którego ryzyko ważone będzie największe, zadania audytowe powinny być realizowane w pierwszej kolejności. Audytor powinien zwrócić uwagę na procesy realizowane w ramach badanego obszaru, dla których ryzyko ważone jest największe i zbadać je w pierwszej kolejności.

Metoda mapy ryzyka klasyfikuje je według prawdopodobieństwa wystąpienia ryzyka i jego znaczenia dla jednostki. Prawdopodobieństwo wystąpienia ustala się w skali od 1 do 5, natomiast znaczenie dla jednostki w skali od 1 do 10. Po ocenie ryzyka, na podstawie przypisanych wartości ze skali prawdopodobieństwa i znaczenia, ryzyko umieszcza się w jednym z czerech kwadratów na osi współrzędnych. Metoda pozwala przypisać ryzyko do jednej z czterech kategorii:

a) zapobiegaj u źródła (duże prawdopodobieństwo wystąpienia i duże znaczenie ryzyka dla jednostki);

b) wykryj i monitoruj (znaczenie duże, ale prawdopodobieństwo wystąpienia ryzyka mniejsze);

c) monitoruj (znaczenie mniejsze, ale prawdopodobieństwo wystąpienia ryzyka duże);

d) minimalna kontrola (małe znaczenie i małe prawdopodobieństwo wystąpienia ryzyka).

Przy stosowaniu tej metody audytor wewnętrzny powinien mieć dużą wiedzę na temat jednostki.

Biorąc pod uwagę akty prawne $\mathrm{i}$ inne opracowania dotyczące kontroli zarządczej i audytu wewnętrznego, można stwierdzić, że głównym narzędziem stosowanym przez audytora wewnętrznego i osobę odpowiadającą za kontrolę zarządczą jest analiza ryzyka. Wykorzystanie analizy ryzyka służy jednak różnym celom, realizowanym w ramach funkcjonowania kontroli zarządczej i audytu wewnętrznego. Analiza ryzyka przeprowadzana jest innymi metodami przez różny krąg osób. Wybrane różnice w stosowaniu analizy ryzyka przez kontrolę zarządczą i audyt wewnętrzny zaprezentowano w tabeli 1. 


\section{Tabela 1}

Analiza ryzyka w kontroli zarządczej i audycie wewnętrznym

\begin{tabular}{|c|c|c|}
\hline Kryteria & Kontrola zarządcza & Audyt wewnętrzny \\
\hline Cel analizy ryzyka & $\begin{array}{l}\text { przypisanie ryzyka do celów i zadań } \\
\text { realizowanych przez jednostkę, } \\
\text { zapobieganie w przyszłości } \\
\text { niekorzystnym zjawiskom } \\
\text { wpływającym na realizację celów } \\
\text { i zadań }\end{array}$ & $\begin{array}{l}\text { opracowanie planu audytu wewnętrznego, } \\
\text { przegląd wstępny realizowanego zadania } \\
\text { audytowego w celu przypisania ryzyka } \\
\text { do realizowanych w badanym obszarze } \\
\text { procesów, usprawnianie procesów, które } \\
\text { przyczyniają się do realizacji zadań i celów } \\
\text { jednostki }\end{array}$ \\
\hline $\begin{array}{l}\text { Osoby uczestniczące } \\
\text { w analizie ryzyka }\end{array}$ & wszyscy pracownicy jednostki & $\begin{array}{l}\text { audytorzy wewnętrzni, kierownik jednostki, } \\
\text { kierownicy poszczególnych działów }\end{array}$ \\
\hline Funkcja analizy ryzyka & zarządzanie ryzykiem & kontrola zarządzania ryzykiem \\
\hline Metody analizy ryzyka & $\begin{array}{l}\text { ustalenie prawdopodobieństwa } \\
\text { wystąpienia ryzyka i skutków jego } \\
\text { zmaterializowania, mapa ryzyka }\end{array}$ & $\begin{array}{l}\text { metody szacunkowe, metody matematyczne, } \\
\text { metody mieszane, mapa ryzyka }\end{array}$ \\
\hline Zadania analizy ryzyka & $\begin{array}{l}\text { wyznaczanie celów jednostki, } \\
\text { skutków materializacji ryzyka, } \\
\text { sposobów monitorowania ryzyka } \\
\text { i jego minimalizowania lub } \\
\text { zapobiegania w przyszłości }\end{array}$ & $\begin{array}{l}\text { kontrola obszarów działalności jednostki } \\
\text { o największym prawdopodobieństwie } \\
\text { wystąpienia nieprawidłowości, wskazanie } \\
\text { słabości kontroli zarządczej w badanym } \\
\text { obszarze i opracowanie zaleceń dotyczących } \\
\text { ich wyeliminowania lub zminimalizowania }\end{array}$ \\
\hline $\begin{array}{l}\text { Sposób udokumentowania } \\
\text { analizy ryzyka }\end{array}$ & rejestr ryzyka & $\begin{array}{l}\text { plan audytu wewnętrznego na przyszły } \\
\text { rok, sprawozdanie z realizacji audytu } \\
\text { wewnętrznego, dokumenty robocze audytu } \\
\text { wewnętrznego }\end{array}$ \\
\hline
\end{tabular}

Źródło: opracowanie własne na podstawie Kotarski, Rosiek (2016), s. 231-241; Łukomska-Szarek (2016), s. 245-246; Zbaraszewska (2016), s. 256.

\section{Szacowanie ryzyka w praktyce}

Inspiracją do przeprowadzenia badań w zakresie analizy ryzyka w kontroli zarządczej i audycie wewnętrznym była „Informacja w o wynikach kontroli funkcjonowania kontroli zarządczej w jednostkach samorządu terytorialnego (dalej: JST) ze szczególnym uwzględnieniem kontroli zarządczej” opublikowana przez Najwyższą Izbę Kontroli (dalej: NIK) w 2011 roku. Głównym celem kontroli była ocena sposobu wdrożenia kontroli zarządczej w jednostkach samorządu terytorialnego oraz wywiązania się z obowiązku prowadzenia audytu wewnętrznego. Badaniem objęto 20 JST, w tym 14 urzędów miast i sześć urzędów gmin. Przedmiotem badań było funkcjonowanie kontroli zarządczej w obszarze zamówień publicznych.

NIK negatywnie ocenił postęp i efekty wprowadzania kontroli zarządczej w badanych jednostkach i wspieranie kierowników przez audytorów wewnętrznych w realizacji celów i zadań. Dotyczyło to skontrolowanych przez NIK wyników zadań zapewniających i czynności doradczych wykonywanych przez audytorów wewnętrznych, które w opinii organu 
dokonującego kontroli nie były wystarczającym źródłem informacji o adekwatności, skuteczności i efektywności całego systemu kontroli zarządczej. W 95\% badanych jednostek stwierdzono brak zarządzania ryzykiem, które jest głównym zadaniem kontroli zarządczej. Udokumentowane wprowadzanie kontroli zarządczej, uwzględniające identyfikację i analizę ryzyka stwierdzono tylko w jednej jednostce. NIK podkreślił, że brak zarządzania ryzykiem przyczynia się do obniżenia jakości analiz ryzyka przeprowadzanych na potrzeby sporządzenia planu audytu wewnętrznego, a to z kolei wpływa na obniżenie efektywności audytu wewnętrznego (Informacja..., 2011).

W przypadku 70\% kierowników urzędów stwierdzono, że nie uczestniczyli oni w szkoleniach z zakresu zarządzania ryzykiem. Kontrolę w zakresie wprowadzania kontroli zarządczej przeprowadzono także w gminnych jednostkach organizacyjnych. W $71 \%$ badanych jednostek pracownicy zostali zapoznani z problematyką kontroli zarządczej, jednak aż $72 \%$ kierowników jednostek nie brało udziału w szkoleniach z zakresu zarządzania ryzykiem. W przypadku 55\% badanych jednostek zadania z zakresu zarządzania ryzykiem zostały przypisane pracownikom, ale monitorowanie zarządzania ryzykiem było prowadzone tylko w 44\% kontrolowanych jednostek. NIK stwierdził też w jednym z urzędów przypadek przypisania audytorowi wewnętrznemu zadań z zakresu zarządzania ryzykiem, co nie było prawidłowym działaniem i wiązało się z wyłączeniem dokonywania przez audytora wewnętrznego oceny systemu kontroli zarządczej w kolejnym roku. W odniesieniu do audytu wewnętrznego oceniono wybór metod analizy ryzyka, które przyczyniły się do wyznaczenia zbyt dużej liczby obszarów ryzyka i wykonywanie zbyt małej w stosunku do potrzeb liczby zadań audytowych w ciągu roku. Działania doradcze dotyczące kontroli zarządczej stwierdzono tylko w $30 \%$ badanych jednostek.

W opinii NIK wynik kontroli świadczył o zbyt małej świadomości kierowników urzędów miast i gmin o korzyściach, jakie przyniosłaby adekwatna, skuteczna i efektywna kontrola zarządcza i niezależny, obiektywny i efektywny audyt wewnętrzny.

W odpowiedzi na kontrolę NIK, Departament Audytu Sektora Finansów Publicznych przeprowadził badania ankietowe w 2561 JST dotyczące audytu wewnętrznego i kontroli zarządczej i opublikował je w maju 2012 roku w opracowaniu Analiza wyników badania ankietowego przeprowadzonego w jednostkach samorzadu terytorialnego z zakresu wybranych zagadnień kontroli zarządczej. Celem badań było określenie stanu wiedzy i podejmowanych działań z zakresu kontroli zarządczej w JST. Tylko w 30\% badanych jednostek stwierdzono zarządzanie ryzykiem. Respondenci wskazali ograniczenia i problemy z zakresu zarządzania ryzykiem. Przede wszystkim dotyczyły one braku ujednoliconego katalogu mierników realizacji, celów, zadań, podzadań dla wszystkich jednostek JST w Polsce, braku regulacji i metodologii w zarządzaniu ryzykiem, braku przekonania co do sensu realizacji kontroli zarządczej w obszarze zarządzania ryzykiem. Podkreślono także brak przepisów prawa dotyczących sposobu dokumentowania prowadzenia kontroli zarządczej a także formy określania misji, celów strategicznych, celów rocznych i monitorowania systemu kontroli zarządczej (Analiza..., 2012). 
W podsumowaniu przeprowadzonej przez NIK kontroli i badań Ministerstwa Finansów można stwierdzić, że w pierwszym okresie wprowadzania w JST kontroli zarządczej wystąpiły liczne problemy dotyczące świadomości osób, na które nałożono taki obowiązek, braku odpowiednich regulacji prawnych i wytycznych w zakresie metodologii kontroli zarządczej, zrozumienia właściwego podziału zadań między kontrolą zarządczą i audytem wewnętrznym. Najwięcej problemów sprawiły obowiązki w zakresie zarządzania ryzykiem, powiązania ryzyka z celami i zadaniami jednostki i jego analizy, co pozwoliłaby ryzyko zminimalizować do akceptowalnego poziomu.

Badania na potrzeby artykułu przeprowadzono w 2017 roku. W tym okresie Ministerstwo Finansów podjęło wiele działań wspierających kierowników jednostek w zakresie wprowadzania kontroli zarządczej. Należą do nich między innymi materiały metodologiczne upowszechniane przez Ministerstwo Finansów dotyczące zarządzania ryzykiem i wyznaczania celów, prezentowanie praktycznych rozwiązań w zakresie kontroli zarządczej, wydawanie biuletynu „Kontrola zarządcza w jednostkach samorządu terytorialnego”.

Badaniem objęto 10 jednostek w województwie zachodniopomorskim (trzy jednostki budżetowe i siedem jednostek samorządu terytorialnego). Jednostki budżetowe to dwie jednostki wojskowe i sąd. Jednostki samorządu terytorialnego to starostwo powiatowe, urząd miasta, jedna gmina miejska i cztery gminy wiejskie. Wykorzystano ankietę i wywiad. Odpowiedzi udzielili audytorzy wewnętrzni badanych jednostek.

We wszystkich badanych jednostkach audyt wewnętrzny prowadzony jest ze względu na ustawowy obowiązek. We wszystkich jednostkach budżetowych, starostwie powiatowym i urzędzie miasta audytorzy są zatrudnieni na umowę o pracę. W pozostałych jednostkach w gminie miejskiej i czterech gminach wiejskich obowiązki w zakresie audytu wewnętrznego prowadzi audytor usługodawca.

We wszystkich badanych jednostkach, w których audytor jest zatrudniony na podstawie umowy o pracę, wyodrębniono jednoosobowe stanowisko audytora wewnętrznego. W roku 2016 w sądzie audytor zrealizował jedno zadanie, w Starostwie Powiatowym - trzy zadania, W Urzędzie Miasta też trzy zadania, w pierwszej jednostce wojskowej zrealizowano dwa zadania a w drugiej - trzy. W gminach wiejskich audytorzy zrealizowali po trzy zadania. Liczba zrealizowanych zadań była podobna w badanych jednostkach i niezależna od formy zatrudnienia audytora wewnętrznego.

We wszystkich badanych jednostkach audytorzy wewnętrzni realizują zadania audytowe poza planem audytu, gdy zachodzi podejrzenie wystąpienia ryzyka prowadzonej działalności. Zadania poza planem audytu są podejmowane na wyraźną sugestię kierownika jednostki.

Audytorzy udzielili odpowiedzi na temat wybranych zagadnień związanych z funkcjonowaniem w ich jednostkach kontroli zarządczej. Pytania dotyczyły zagadnień związanych z wyznaczaniem celów i zadań obszarów działalności jednostki i przypisywanego im ryzyka. Odpowiedzi audytorów dotyczące kontroli zarządczej przedstawiono w tabeli 2. 
Tabela 2

Wybrane zagadnienia dotyczące funkcjonowania kontroli zarządczej w wybranych jednostkach

\begin{tabular}{|c|c|c|}
\hline Pytania zadane audytorom & Odpowiedzi audytorów & Odpowiedzi audytorów \\
\hline $\begin{array}{l}\text { Kto wykonuje czynności } \\
\text { związane z kontrolą } \\
\text { zarządczą ? }\end{array}$ & $\begin{array}{l}\text { wyznaczony przez kierownika jednostki } \\
\text { pracownik (takiej odpowiedzi udzieliło } \\
9 \text { respondentów: audytorzy z sądu, jednostek } \\
\text { wojskowych, starostwa powiatowego, gminy } \\
\text { miejskiej i gmin wiejskich) }\end{array}$ & $\begin{array}{l}\text { audytor z Urzędu Miasta } \\
\text { odpowiedział, że nie wie kto } \\
\text { wykonuje czynności związane } \\
\text { z kontrolą zarządczą }\end{array}$ \\
\hline $\begin{array}{l}\text { Czy w procesie kontroli } \\
\text { zarządczej wyznaczono cele } \\
\text { prowadzonej działalności? }\end{array}$ & $\begin{array}{l}\text { tak dla całej jednostki (takiej odpowiedzi } \\
\text { udzieliło } 8 \text { respondentów: audytorzy z sądu, } \\
\text { jednostek wojskowych, gminy miejskiej } \\
\text { i gmin wiejskich) }\end{array}$ & $\begin{array}{l}\text { audytor z Urzędu Miasta } \\
\text { odpowiedział, że nie wie } \\
\text { czy zostały wyznaczone cele } \\
\text { prowadzonej działalności, } \\
\text { a audytor ze Starostwa } \\
\text { Powiatowego, że cele jednostki nie } \\
\text { zostały wyznaczone }\end{array}$ \\
\hline $\begin{array}{l}\text { Czy wyznaczonym celom } \\
\text { przyporządkowano mierniki } \\
\text { ich wykonania i wartości } \\
\text { docelowe? }\end{array}$ & $\begin{array}{l}\text { tak dla wszystkich celów (takiej odpowiedzi } \\
\text { udzieliło } 8 \text { respondentów: audytorzy z sądu, } \\
\text { jednostek wojskowych, gminy miejskiej } \\
\text { i gmin wiejskich) }\end{array}$ & $\begin{array}{l}\text { audytor z Urzędu Miasta } \\
\text { odpowiedział, że nie wie czy } \\
\text { wyznaczono cele i mierniki ich } \\
\text { wykonania, a audytor pracujący } \\
\text { w Starostwie Powiatowym, } \\
\text { odpowiedział, że w jednostce } \\
\text { nie zostały wyznaczone mierniki } \\
\text { wykonania celów i ich wartości } \\
\text { docelowe }\end{array}$ \\
\hline $\begin{array}{l}\text { Czy w procesie kontroli } \\
\text { zarządczej wyznaczone } \\
\text { zostało ryzyko związane } \\
\text { z osiągnięciem celów } \\
\text { działalności? }\end{array}$ & $\begin{array}{l}\text { tak dla wszystkich obszarów (takiej } \\
\text { odpowiedzi udzieliło } 8 \text { respondentów: } \\
\text { audytorzy z sądu, jednostek wojskowych, } \\
\text { gminy miejskiej i gmin wiejskich) }\end{array}$ & $\begin{array}{l}\text { audytor z Urzędu Miasta } \\
\text { odpowiedział, że nie wie, czy } \\
\text { ryzyko zostało wyznaczone, } \\
\text { a audytor ze Starostwa } \\
\text { Powiatowego, że nie zostało } \\
\text { wyznaczone }\end{array}$ \\
\hline $\begin{array}{l}\text { Kto wziął udział w procesie } \\
\text { identyfikacji ryzyka dla } \\
\text { obszarów działalności } \\
\text { jednostki? }\end{array}$ & $\begin{array}{l}\text { kierownicy poszczególnych wydziałów } \\
\text { (takiej odpowiedzi udzieliło } 7 \text { respondentów: } \\
\text { audytorzy jednostek wojskowych, gminy } \\
\text { miejskiej i gmin wiejskich), audytor } \\
\text { pracujący w sądzie oprócz kierowników } \\
\text { poszczególnych wydziałów wskazał } \\
\text { też pracowników wyznaczeni przez } \\
\text { kierowników poszczególnych wydziałów }\end{array}$ & $\begin{array}{l}\text { audytor z Urzędu Miasta } \\
\text { odpowiedział, że nie wie, kto } \\
\text { bierze udział w wyznaczaniu } \\
\text { ryzyka dla poszczególnych } \\
\text { obszarów działalności jednostki, } \\
\text { a audytor ze Starostwa } \\
\text { Powiatowego, że ryzyko nie } \\
\text { zostało wyznaczone więc nie } \\
\text { wskazał odpowiedzi w tym pytaniu }\end{array}$ \\
\hline
\end{tabular}

Źródło: opracowanie własne na podstawie ankiety badawczej.

W ośmiu badanych jednostkach są wykonywane czynności związane z kontrolą zarządczą przez wyznaczonych pracowników. Dotyczy to wyznaczenia celów i zadań dla poszczególnych obszarów prowadzonej działalności, przyporządkowania im mierników wykonania i określenia ryzyka realizacji celów i zadań w poszczególnych obszarach działalności jednostki. Audytorzy tych jednostek (sąd, jednostki wojskowe, gmina miejska, gminy wiejskie) potwierdzili, że wykorzystują wyznaczone w kontroli zarządczej ryzyko związane z realizacja celów i zadań jednostki do analizy ryzyka wykonywanej na potrzeby planu audytu wewnętrznego. Analiza ryzyka na potrzeby audytu wewnętrznego odbywa się 
wszędzie metodą matematyczną, która jest najbardziej obiektywna i dobrze udokumentowana. W tych jednostkach audytorzy wewnętrzni wykonywali zadania doradcze związane z organizacją kontroli zarządczej.

W dwóch badanych jednostkach (Urząd Miasta i Starostwo Powiatowe) audytorzy w analizie ryzyka na potrzeby planu audytu nie uwzględniają ryzyka wyznaczonego w procesie kontroli zarządczej. Audytor z Urzędu Miasta nie wie, czy w procesie kontroli zarządczej wyznaczono cele, zadania, mierniki realizacji celów i zadań, ryzyko dla poszczególnych obszarów działalności. Audytor ze Starostwa Powiatowego potwierdził, że w jednostce, w której pracuje brakuje formalnej identyfikacji celów, zadań, mierników realizacji celów i zadań a także oceny ryzyka w procesie kontroli zarządczej, co uniemożliwia ich wykorzystanie przy analizie ryzyka na potrzeby stworzenia planu audytu wewnętrznego.

Można wysnuć wniosek, że w Urzędzie Miasta i Starostwie Powiatowym nie jest udokumentowana procedura zarządzania ryzykiem, a tym samym główne zadanie kontroli zarządczej, jakim jest zarządzanie ryzykiem może nie być realizowane w sposób wystarczający i efektywny. Brakuje bowiem standardów oceny działalności poszczególnych obszarów funkcjonowania jednostki. Nie jest oceniany stopień realizacji celów i zadań. Brakuje też wyznaczenia narzędzi reakcji na ewentualne ryzyko, które może się pojawić przy prowadzeniu działalności. Wyznaczony sposób reakcji na ryzyko mógłby zapobiec jego powstaniu lub go zminimalizować do poziomu akceptowanego przez kierownika jednostki.

Można podać w wątpliwość jakość kontroli zarządczej, a tym samym jakość audytu wewnętrznego w Urzędzie Miasta i Starostwie Powiatowym. Brak zarządzania ryzykiem w kontroli zarządczej lub jego mała efektywność przyczyniają się do obniżenia jakości analizy ryzyka na potrzeby planu audytu wewnętrznego. Można stwierdzić, że przyczyną takiego stanu kontroli zarządczej i audytu wewnętrznego w obu jednostkach może być brak świadomości kierowników o potrzebie wykonywania kontroli zarządczej i korzyściach dla jednostki z wprowadzenia w życie procedur z nią związanych.

\section{Uwagi końcowe}

Przeprowadzone badania pozwalają stwierdzić, że w większości jednostek procedury wykonywania kontroli zarządczej są udokumentowane, a ryzyko realizacji celów i zadań poszczególnych obszarów jest określone i oceniane. Dzięki temu ryzyko poszczególnych obszarów działalności jednostki, wyznaczone przez pracowników zajmujących się kontrolą zarządczą jest wykorzystywane do analizy ryzyka na potrzeby panu audytu wewnętrznego, co zwiększa jego skuteczność i efektywność. W dwóch badanych jednostkach brakuje jednak opisanych procedur zarządzania ryzykiem, co podaje w wątpliwość prawidłowość i skuteczność wykonywanej w tych jednostkach kontroli zarządczej. Taki stan kontroli zarządczej po wielu latach obowiązywania i ujednolicenia przez Ministerstwo Finansów procedur jej stosowania, jest naganny i wymaga reakcji organów, które działalność jednostek sfery finansów publicznych kontrolują i nadzorują. 


\title{
Literatura
}

Analiza wyników badania ankietowego przeprowadzonego w jednostkach samorzadu terytorialnego z zakresu wybranych zagadnień kontroli zarządczej (2012). Warszawa: Departament Audytu Sektora Finansów Publicznych. Pobrane z: http://www.mf.gov.pl/c/document_library/get_file?uuid=4304deb8-10c7-4c97-9a16-7da8d961 ebd7\&groupId=764034 (10.05.2017).

Informacja o wynikach kontroli funkcjonowania kontroli zarzadczej w jednostkach samorzadu terytorialnego ze szczególnym uwzględnieniem audytu wewnętrznego (2011). Gdańsk: Najwyższa Izba Kontroli delegatura w Gdańsku. Pobrane z: https://www.nik.gov.pl/kontrole/wyniki-kontroli-nik/kontrole,8628.html (10.05.2017).

Kotarski, D., Rosiek, I. (2016). Ocena funkcjonowania kontroli zarządczej w jednostce oświatowej na przykładzie samorządowego przedszkola w Słubicach. Finanse, Rynki Finansowe, Ubezpieczenia, 6 (84/1), 231-241.

Komunikat nr 23 Ministra Finansów z dnia16 grudnia 2009 r. w sprawie standardów kontroli zarządczej dla sektora finansów publicznych (Dz. Urz. Min. Fin. nr 15, poz. 84).

Komunikat Ministra Rozwoju i Finansów z dnia 17 czerwca 2016 r. w sprawie standardów audytu wewnętrznego dla jednostek sektora finansów publicznych (Dz. Urz. Min. Rozw. i Fin., poz. 28).

Łukomska-Szarek, J. (2016). Ewaluacja ryzyka w systemie kontroli zarządczej oświatowej jednostki budżetowej. Finanse, Rynki Finansowe, Ubezpieczenia, 6 (84/1), 245-246.

Ministerstwo Finansów (2011). Zarządzanie ryzykiem. Informacje ogólne. Warszawa: Departament Audytu Sektora Finansów Publicznych. Pobrane z: http://www.mf.gov.pl/ministerstwo-finansow/dzialalnosc/finanse-publiczne/ kontrola-zarzadcza-i-audyt-wewnetrzny/kontrola-zarzadcza- (10.05.2017).

Podręcznik audytu wewnętrznego w administracji publicznej (2003). Warszawa: Ministerstwo Finansów. Pobrane z: http://www.mf.gov.pl/c/document_library/get_file?uuid=d25de3cc-46cc-4765-8dfb-3872090eaa18\&groupId $=764034(10.05 .2017)$.

Rozporządzenie Ministra Finansów z dnia 4 września. 2015 r. w sprawie audytu wewnętrznego oraz informacji o pracy i wynikach tego audytu (Dz.U. poz. 1480).

Ustawa z dnia 27 sierpnia 2009 r. o finansach publicznych (t.j. Dz.U. 2016, poz.1870, z późn. zm.).

Zbaraszewska, A. (2016). Analiza ryzyka na potrzeby kontroli zarządczej w placówkach oświatowych. Finanse, Rynki Finansowe, Ubezpieczenia, 6 (84/1), 255-265.

\section{INTERNAL AUDIT AND MANAGEMENT CONTROL IN THE RISK ASSESSMENT OF CONDUCTED ACTIVITY IN LOCAL GOVERNMENT UNITS}

\begin{abstract}
Purpose - The objective of this article is to present the results of researches concerning the relation between internal audit and management control in terms of risk assessment of conducted activity to determine an audit plan.

Design/methodology/approach - The following research methods were used: analysis of subject literature, analysis of legal acts and analysis of comparisons. Moreover, research questionnaire and interview were utilized. The questionnaire was addressed to internal auditors employed in local government units and budgetary units. Supplements for surveys were interviews conducted with respondents. The researches were conducted in 2017.

Findings - Researches conducted in units of the public finance sphere and the results published by the NIK from the control carried out in 2017 concerning the functioning of management control in local government units (with particular regard to internal audit) were used to formulate conclusions.

Originality/value - The article presents a rarely discussed problem of the links between internal audit and management control in the range of risk assessment of business activity for the purposes of the internal audit plan. The author of the study has not met so far with the researches concerning the problem determined in the article.
\end{abstract}

Keywords: internal audit, management control, risk, audit plan, objectives, measures

\section{Cytowanie}

Zaleska, B. (2017). Rola audytu wewnętrznego i kontroli zarządczej w szacowaniu ryzyka prowadzonej działalności w jednostkach samorządu terytorialnego. Finanse, Rynki Finansowe, Ubezpieczenia, 3 (87/1), s. 165-174. DOI: 10.18276/frfu.2017.87/1-15. 